\title{
EFFECT OF IRRIGATION REGIME ON WHEAT (Triticum aestivum L.) GROWTH AND YIELD IN SEMI-ARID TROPICS
}

\author{
J.E. ONYIBE \\ NAERLS, Ahmadu Bello University, PMB 1067, Zaria, Nigeria
}

\begin{abstract}
Field trials were conducted at irrigation Research stations of the institute for Agricultural Research, Kadawa $\left(11^{\circ} 39^{\prime} \mathrm{N}, 08^{\circ} 27^{\prime} \mathrm{E} 500 \mathrm{asl}\right)$. The objective was to study the effect of irrigation regime $(60,75$ and $90 \%$ Available Soil Moisture (ASM) on the growth and yield of two recently introduced wheat cultivars (Siete cerros and Pavon 76). The result revealed that increase of irrigation regime from 60 to $90 \%$ ASM did not significantly affect most of the growth, yield and yield parameters evaluated in the study. Each increased in irrigation regime however increased days to maturity, water use and thermal time but decreased water use efficiency. Pavon 76 produced superior grain yield than Siete ceros only in one season. Pavon 76 had a higher leaf area index (LAl), more tillers and spikes $/ \mathrm{m}^{2}$ and larger grain size, but had shorter plants, lower grain weight and grain number/spike and matured earlier than Siete cerros. Irrigation level of $60 \%$ ASM is recommended for both varieties in the Sudan savanna ecology. At this ASM the highest water use efficiency of $4.0-4.8 \mathrm{~kg} / \mathrm{mm} / \mathrm{ha}$ was obtained and grain yield was not significantly compromised. Positive and highly significant correlations between grain yield and attribute such as number of spike/ $\mathrm{m}^{2}$, grain weight/spike, plant height and harvest index were found.
\end{abstract}

Keywords : Available soil moisture, moisture stress, wheat cultivars, yield, Nigeria.

\author{
RESUME \\ EFFET DU RÉGIME D' IRRIGATION SUR LA CROISSANCE ET LE RENDEMENT DU BLÉ (Triticum aestivUT L) \\ EN ZONE TROPICALE SEMI-ARIDE
}

Des essais en champ ont été conduits dans les stations de recherche de l'Institut pour la Recherche

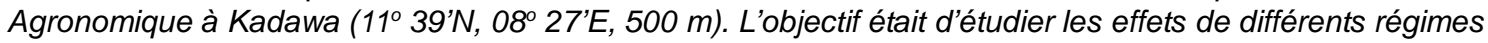
d'irrigation (60-75-90 \% de la réserve en eau utile du sol ou $R U$ ) sur la croissance et le rendement de 2 nouveaux cultivars de blé (Siete cerros et Pavon 76). Le résultat était que l'augmentation de l'irrigation de 60 à $90 \%$ de la RU du sol n'a pas significativement affecté la croissance, le rendement et les paramètres du rendement évalués dans l'étude. Chaque augmentation de l'irrigation a accru la durée de maturité, la consommation d'eau et la somme des températures, mais a diminué l'efficacité d'utilisation de l'eau. Pavon 76 a dépassé Siete cerros en rendement seulement une fois. Pavon 76 avait un plus grand indice de surface foliaire, plus de talles et d'épis $/ \mathrm{m}^{2}$ et de plus gros grains. Mais il avait aussi des plantes plus courtes, un moindre poids de mille grains, un faible nombre de grains/épis, ainsi qu'une maturité plus précoce que Siete cerros. L'irrigation à $60 \%$ de la RU est recommendée pour les 2 variétés en zone soudano sahélienne. Pour ce régime, la plus forte efficacité d'utilisation de l'eau est atteinte avec un niveau de 4 à $4,8 \mathrm{~kg} / \mathrm{mm} / \mathrm{ha}$, sans compromettre le rendement en grains. L'étude a également montré des corrélations positives très significatives entre le rendement en grain et ses composantes telles que le nombre d'épis $/ \mathrm{m}^{2}$, le pois de grains / épis, la hauteur de plante et l'indice de récolte.

Mots clés : réserve en eau utile du sol, stress hydrique, cultivars de blé, rendement, Nigeria. 


\section{INTRODUCTION}

Plant response to varying degrees of water regime has been a subject of considerable study and review (Slatyer, 1967 ; Kajdi, 1993 ; and Khehr et al, 1996). Yet the question of how water regime interacts with other cultural practices to affect growth, yield and quality of crops remain one of the important problems in crop agriculture because of the dynamics of the interactions. In several dimensions conclusive explanations of these interactions have not been achieved. Current emphasis however appear to be on understanding the plastic responses of crop genotypes to soil water status and the determination of climate plant and soil relationships (Benbi, 1994) that would enhance appropriate scheduling of irrigation. Wheat cultivars respond differently to irrigation treatments. Studies by Kumar and Yayock (1980), Kumar (1985), Falaki (1994) and recently by Abubakar (1999) have shown considerable variations in yields between cultivars in Nigeria. Their reports and that of Negedu (1994) also show seasonal variations in yields of individual cultivars. The differences in yields among cultivars, and between seasons are commonly associated with differences in growth and yield attributes (Negedu, 1994 ; Falaki, 1994 and Abubakar, 1999) and to genetic differences (Raja ram and van Ginkel, 1996).

Several workers have observed that the yield of wheat was enhanced if irrigation was sustained at $50 \%$ or higher available soil moisture levels (Erie 1962 ; Kumar, 1979 ;

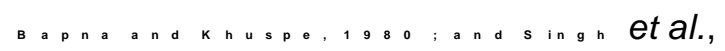
1980). These results implicate the need for determination of the response of newly developed wheat varieties under different moisture regimes.

In the light of the above, this study was initiated among other things to evaluate the effect of three irrigation regimes on growth and yield of two newly introduced wheat cultivars.

\section{MATERIAL AND METHOD}

Field Experiments were conducted over three seasons, 1995/96, 1996/97 and 1997/98 dry seasons at the Institute for Agriculture (IAR/ $A B U)$ irrigation Research Station at Kadawa (Figure 1) $\left(11^{\circ} 39^{\prime} \mathrm{N} 08^{\circ} 15 \mathrm{E}\right.$ and $500 \mathrm{~m}$ above sea level) in the Sudan ecology of Nigeria.

The soil was sandy loam, $\mathrm{pH}>7.2-8.0$, CEC (meq/100) of 5.89-6.21, exchangeable $\mathrm{Na}^{++}$ of $0.152-0.182, \mathrm{~K}^{+}$of $0.202-0.268, \mathrm{Ca}^{++}$of 2.16-2.93, Total $\mathrm{N}$ of) 0.041-0.048, and Total $\mathrm{P}$ (ppm) 29.36-33.38. The water table depths of the sites used in the study determined by the method described by Nwa (1982) on the $20^{\text {th }}$ of each month of the study averaged $77 \mathrm{~cm}$ in 1995/ 96, over $100 \mathrm{~cm}$ in $1996 / 97$ and $92 \mathrm{~cm}$ in $1997 /$ 98. Three irrigation levels ( $60 \%, 75 \%$ and $90 \%$ ASM) and two spring semi-dwarf wheat varieties (Triticum aestivum L.) viz, Siete cerros (maturing in about 10 -115 days) and Pavon 76 (maturing in about 90 - 102 days) were evaluated in three replicates laid out in a Randomized complete Block Design (RCBD). Moisture levels were determined from a centrally position access tube using a Toxler neutron probe in each plot. At the commencement of trial in each year, a field was calibrated with probe and obtained calibration curves were used to estimate both field capacity and wilting point in order to determine moisture depletion pattern. Using this technique, at field capacity at -0.2 bar, volumetric water content averaged $20.87 \mathrm{~cm}$ while that at permanent wilting point (PWP) measured at -15 bar was $8.46 \mathrm{~cm}$. Thus available soil moisture was 12.41 $\mathrm{cm}$. Based on this value, which did not vary significantly during the study, the irrigation regimes were imposed (at $60 \%, 75 \%$ and 90 $\%$ level of availability) using an irrigation pump fitted with a water meter. The experimental land was irrigated, ploughed and harrowed three times to obtain a fine tilt. Basins were constructed manually and its raised borders (70 $\mathrm{cm}$ height) were carefully compacted to minimize seepage. The internal basin dimensions were $4 \times 3 \mathrm{~m}$. The seeds were treated with Apron plus 50 DS at the rate of $10 \mathrm{~g} / \mathrm{kg}$ of seed before sowing. Seeding rate adopted was $120 \mathrm{~kg} / \mathrm{ha}$. Corresponding quantity of seed for each plot was weighed and used completed. Planting was conducted based on the sowing date treatments. Seeds were sown in rows of $20 \mathrm{~cm}$ rows by drilling. The first and the third rows each side was treated as border rows, while the second 
row were used for destructive sampling. Also along the length of the plot, $0.25 \mathrm{~cm}$ was treated as border area. Thus giving a net plot size of 7 $\mathrm{m}^{2}$. First dose of $60 \mathrm{~kg}$ each of $\mathrm{N}, \mathrm{P}_{2} \mathrm{O}_{5}$ and $\mathrm{K}_{2} \mathrm{O} /$ ha was applied basally at planting. A compound fertilizer was used to supply the nutrient. A second dose of $60 \mathrm{~kg} \mathrm{~N} / \mathrm{ha}$ was applied at 6 six weeks after sowing (WAS) using Urea $(46 \% \mathrm{~N})$ as source of Nitrogen. The same fertilizer regime was adopted throughout the study. Weeds were controlled manually by hoe weeding at 3,5 and 7 WAS. The crop was harvested at physiological maturity stage 11.4 on Feekes scale illustrated by Large (1954). Cutting the crops with a sharp sickle as close as possible to the ground level did harvesting. The harvested net plots were bundled into sheaves, dried on the field, weighed, threshed and winnowed. Dry matter per meter square was determined at 3, 6, 9 and 12 WAS. The plants in $0.5 \mathrm{~m}$ linear row carefully uprooted and the root washed free of soils and other foreign particles. The sample was then oven dried at $60^{\circ} \mathrm{C}$ until samples attained constant weight. An electronic balance was used to weigh the samples. Leaf area index was determined by method described by Bell and Fischer (1994). The numbers of tillers, spike per $\mathrm{m}^{2}$, were recorded by counting the individual plant in the samples uprooted from a $0.5 \mathrm{~m}$ linear row at 6 WAS. Plant height was determined from the main shoot of three- tagged plants in each plot from ground level to the tip of spike excluding the awns. Plant height was measured at maturity using a meter rule. Length of spike, weight and number of grains per spike were determined from 5 -tagged plants in each plot. Three samples of $250 \mathrm{~g}$ each were carefully weight and 1000-grain determined from the sample. Measurement of grain yield preceded the determination of this parameter from yield samples from each plot. Grain yield was determined by measurement of weight grains obtained after threshing and winnowing from the $7 \mathrm{~m}^{2}$ net plot. The grain yields per net plot was extrapolated to per hectare. Water use efficiency was derived from the ratio of grain yield from a plot to the total irrigation water applied to the same plot (Michael, 1978).

All data collected were subjected to analysis of variance described by Snedecor and Cockran
(1967). Growth and yield component data were compared using Duncan Multiple Range Test (DMRT) (Duncan, 1955).

\section{RESULTS}

\section{GROWTH}

The result on dry matter shows that the differences due to variety in terms of dry matter accumulation was not significant throughout the sampling periods in both 1995/96 and 1996/97 seasons (table 1). In 1997/98 season varietal differences was significant, at 3 and 6 WAS only where Siete cerros produced higher dry matter per $\mathrm{m}^{2}$ than Pavon 76 . The effect of irrigation regime was not significant. All the interactions were not significant in the three seasons.

In all the three seasons, differences due to variety in terms of LAI was significant at 6 and 9 WAS in which Pavon 76 produced higher LAI than Siete cerros (table 2). The effect of irrigation regime was not significant at initial two stages of sampling but significant at both 9 and 12 WAS in the three seasons. LAI of plots irrigated at 60 $\%$ and $75 \%$ ASM on the one hand, and that of $75 \%$ and $90 \%$ ASM on the other were similar at 9 WAS in the three seasons. At 12 WAS, irrigation at $60 \%$ and $75 \%$ ASM; and at $75 \%$ and $90 \%$ ASM produced similar LAI in 1995/96 Season (table 2). In 1996/97 season (table 2) each increase in available soil moisture increased LAI at 12 WAS. In 1997/98, irrigation at 60 and $75 \%$ ASM produced similar LAI that was lower than that of irrigation at $90 \%$ ASM at 12 WAS (table 2).

Pavon 76 produced more tillers than Siete cerros (table 3). The effect of irrigation regime on tiller number was not significant throughout the experiment.

Siete cerros took longer time to mature than Pavon 76 (table 3). Increased in available soil moisture from 60 to $90 \%$ significantly increased the number of days to maturity. The difference between 75 and $90 \%$ ASM was however not significant. When each of the varieties was examined across the irrigation levels (table 4), it was found that the duration to maturity of both varieties at $60 \%$ was lower than at 75 and $90 \%$ ASM that were similar. When the two varieties were compared at each irrigation level, it was observed that Pavon 76 matured earlier at all stress levels than Siete cerros in the three years. 


\section{GRAIN YIELD AND YIELD COMPONENTS}

The effect of variety on grain yield was significant only in 1996/97 season in which Pavon 76 produced a higher grain yield than Siete cerros (table 5). Similarly, the effect of irrigation level differed significantly only in one season. Irrigating at $90 \%$ ASM produced higher grain yield than at 60 and $75 \%$ ASM. The combined analysis of the first season and the third season, the second and third season revealed that the differences due to variety, and irrigation level did not reach the level of significance (table 5).

The data in table 3 showed that Pavon 76 produced more spikes $/ \mathrm{m}^{2}$ than Siete cerros. Increasing irrigation frequency did not affect the spike number $/ \mathrm{m}^{2}$ in the three seasons. Grain weight/spike of Siete cerros was significantly higher than that of Pavon 76 in both 1996/97 and 1997/98 seasons. Siete cerros also had higher number of grains/spike than Pavon 76. The irrigation levels evaluated in the study did not significantly affect the number of grains/spike. Pavon 76 had heavier grains than Siete cerros (table 5). Increase of irrigation frequency from 60 to $90 \%$ ASM decreased the grain size though there were no significant differences between irrigation at
60 and $75 \%$ ASM in both 1996/97 and 1997/98 seasons and between 75 and $90 \%$ ASM in 1996/97 season. Pavon 76 produced higher Harvest Index (HI) than Siete ceros (table 5).

\section{WATER USE EFFICIENCY}

Water use efficiency (WUE) of Pavon 76 was consistently higher than that of Siete cerros throughout the study (table 6). Each increase in irrigation frequency from 60 to $90 \%$ ASM significantly depressed the WUE. The result also showed that WUE of each variety decreased with each increased in irrigation frequency in the three seasons (table 6).

\section{CORRELATION ANALYSIS}

In all the three seasons grain yield was found to have a positive and highly significant relationships with number of spike $/ \mathrm{m}^{2}$, tiller number, plant height, duration of grain filling, length of spike, and grain wt/spike (tables 7ac). Grain yield also had a strong association with parameters such as number of grain/spike and 1000-grain weight that were found to be highly significant only in $1997 / 98$. The correlation between number of grains/spike and 1000 grain weight was highly significant but negative throughout the study. WUE correlated with grain yield significantly. 

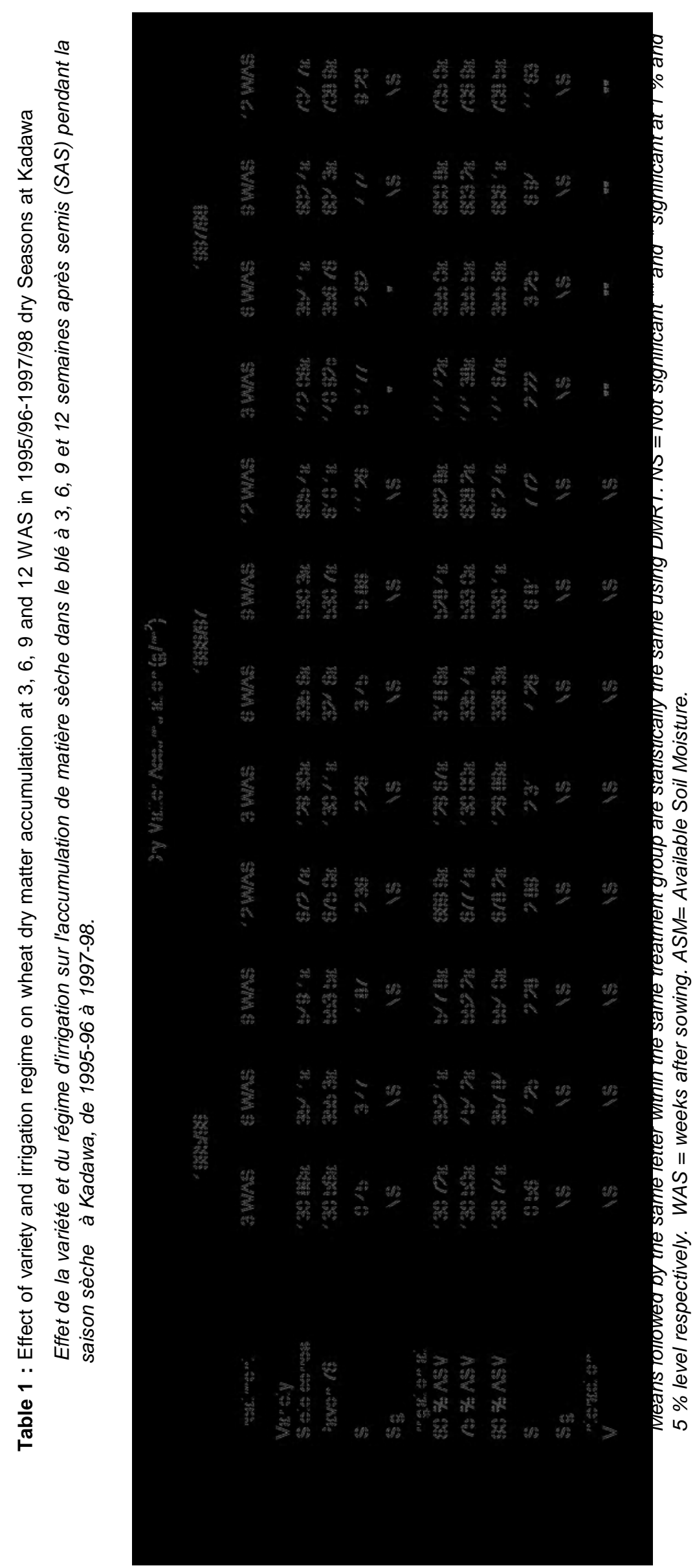

Agronomie Africaine 16 (1) : 45-58 (2004) 


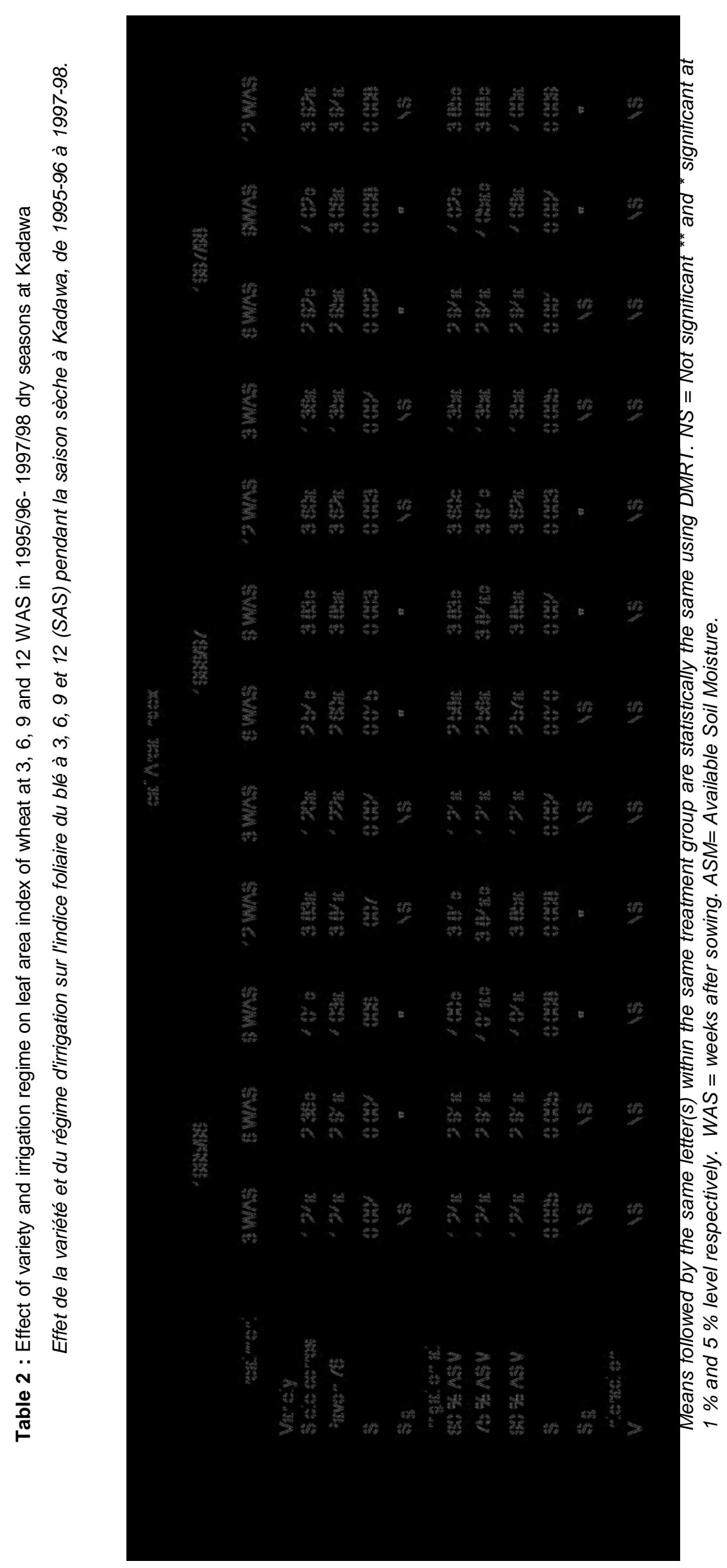



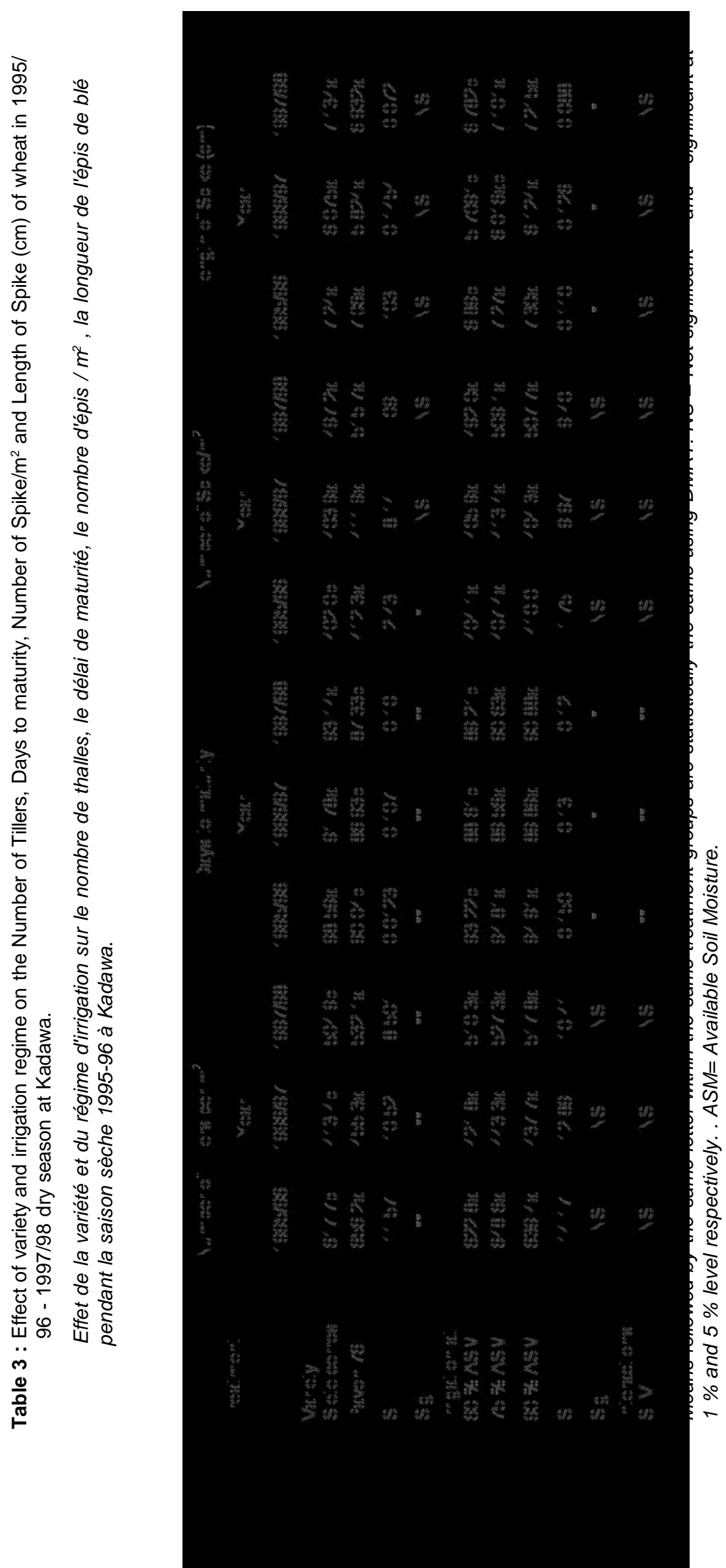

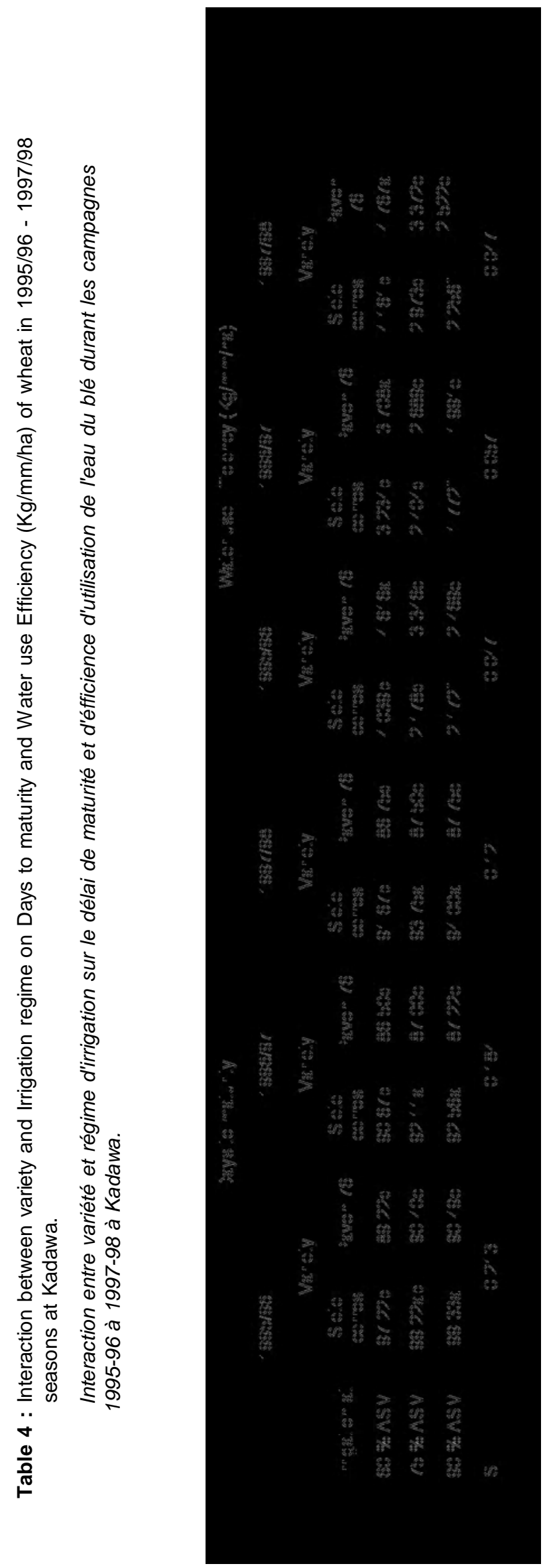

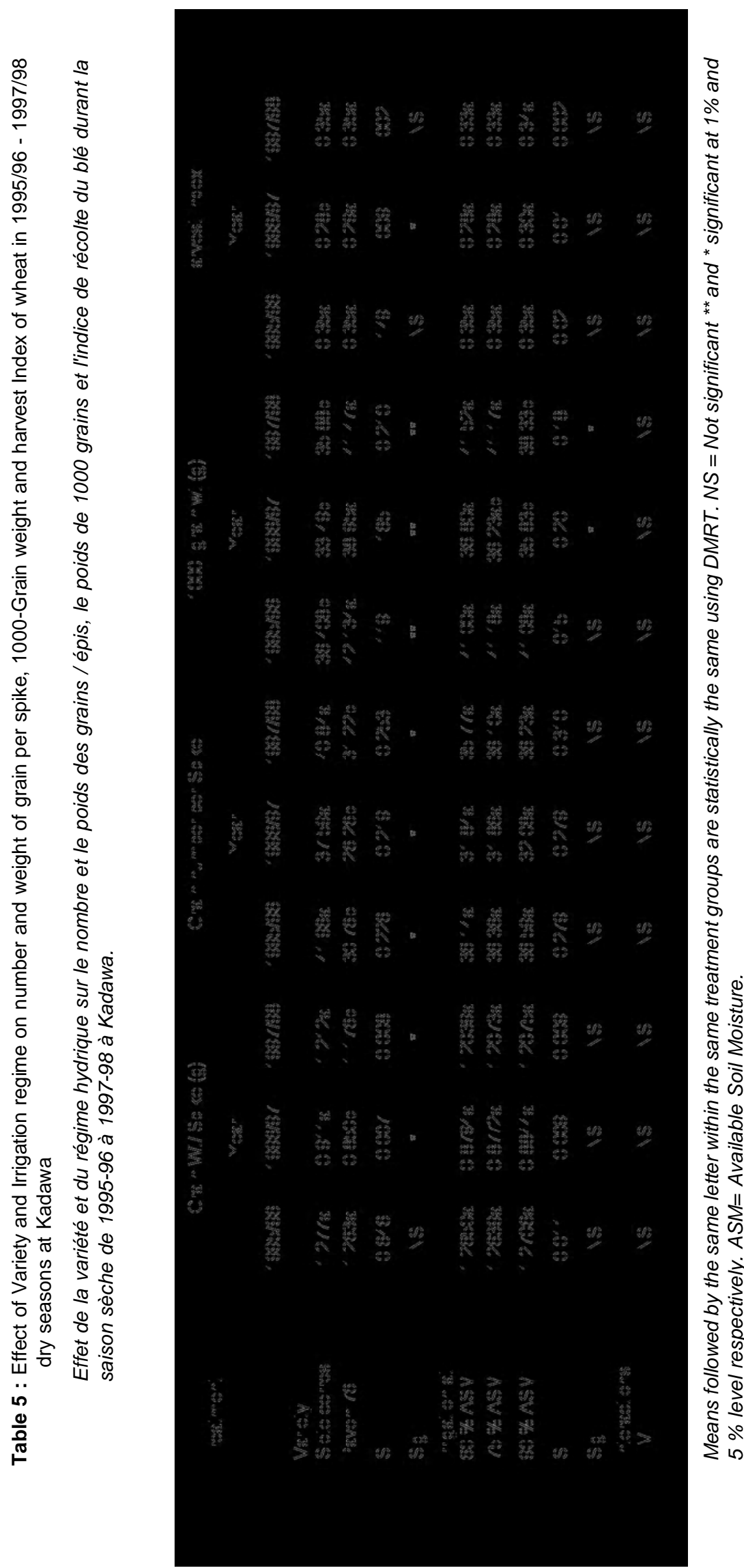


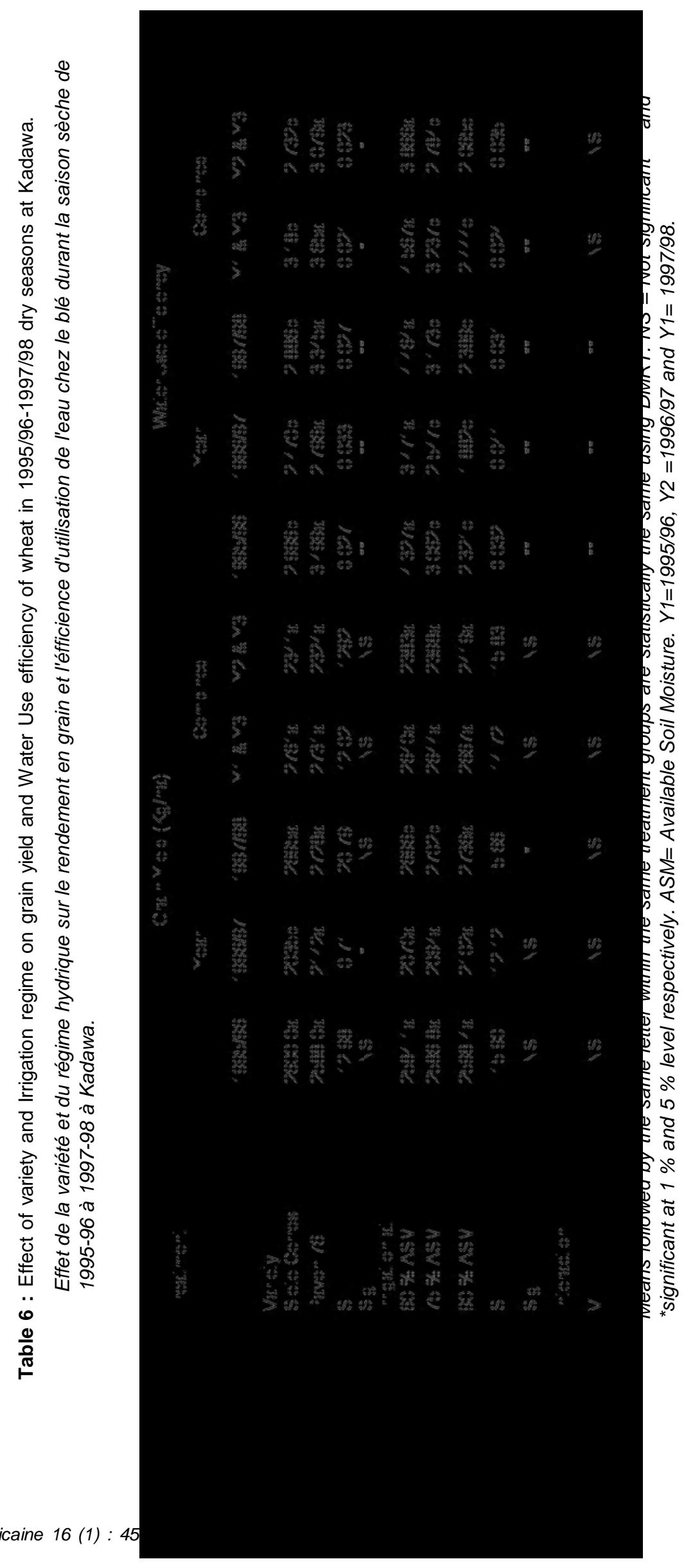




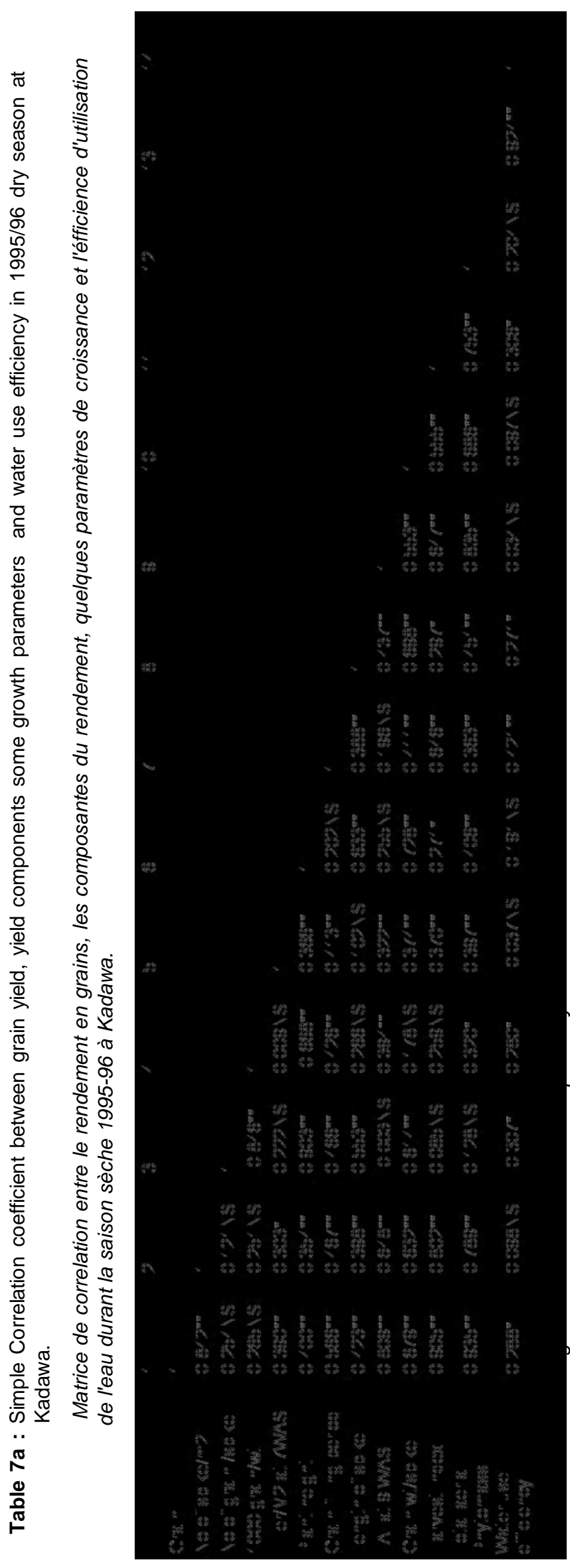




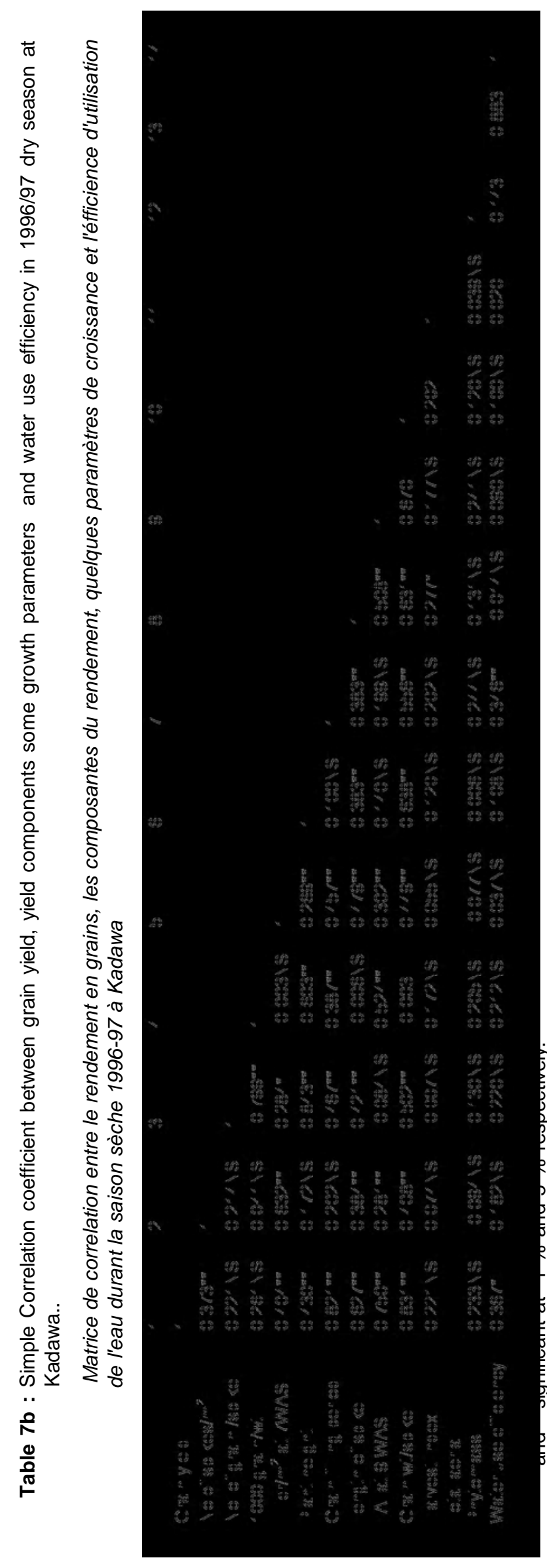




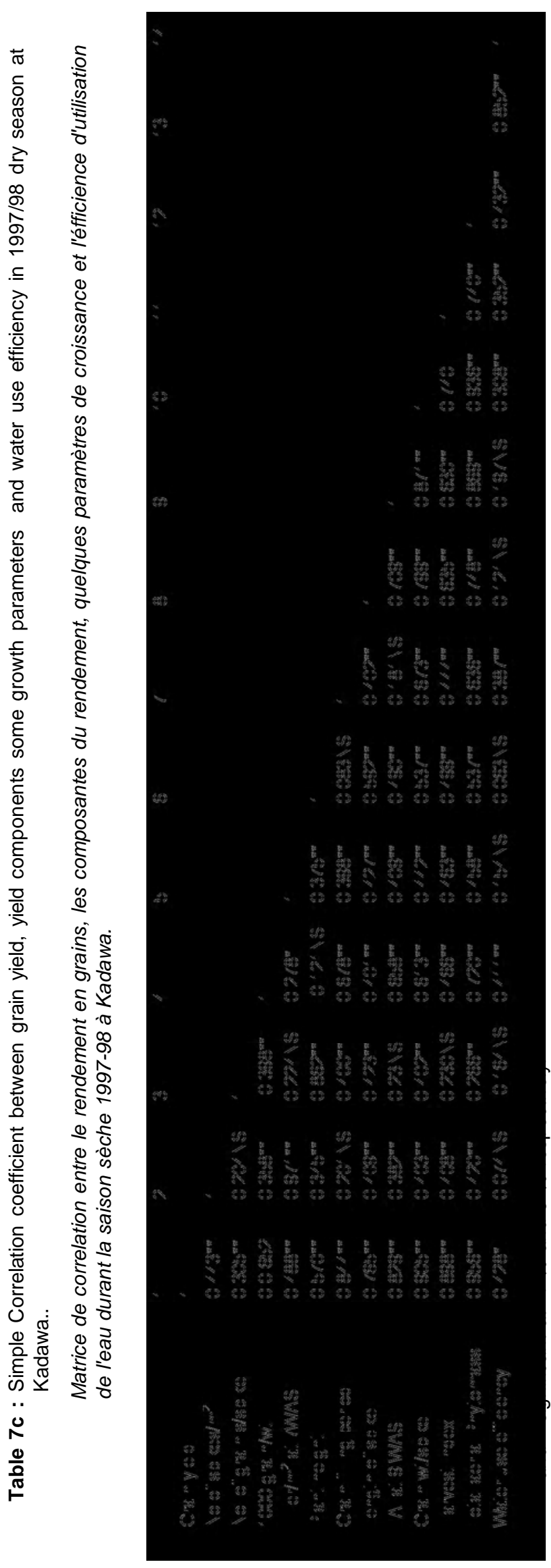




\section{DISCUSSION}

\section{PERFORMANCE OF CULTIVARS}

The study revealed considerable similarities and some differences in the growth of the Siete cerros and Pavon 76. The trend of dry matter accumulation and leaf area indices (LAl) of the two cultivars was similar. This may be due to the fact that both cultivars have similar genetic background having been developed from Nario 10 (Hanson et al. 1982). The response to agronomic treatments among cultivars of with similar genotypes did not differ in the studies by Villare et al. 1992, Stapper and Fischer 1990, as in this current study.

Leaf Area Index increased progressively until 9 WAS and thereafter decreased at 12 WAS in both cultivars. Benbi (1994) and Abubakar (1999) also observed similar decrease of LAI among wheat cultivars after anthesis.

The study revealed some consistency in grain yield superiority of Pavon 76 over Siete cerros in contrast to Abubakar (1999) findings that indicated sustained superiority of Siete cerros over Pavon 76. The factors responsible for the superiority of Pavon 76 over Siete cerros may include higher number of tillers and spikes $/ \mathrm{m}^{2}$, larger grain size, and higher harvest index. However the higher number and weight of grain / spike of Siete cerros could not be completely compensated for its lower number of tiller and spike $/ \mathrm{m}^{2}$ compared with Pavon 76 . The present finding agrees with the reports by Hanson et al. (1982), Orakwe and Olugbemi (1990) that predicted superior yields from Pavon 76 over Siete cerros.

\section{EFFECT OF IRRIGATION}

Increasing irrigation regime from $60 \%$ to $90 \%$ ASM only slightly enhanced growth attributes such as dry matter accumulation, LAI, tiller number $/ \mathrm{m}^{2}$ and plant height. The marginal increases in these attributes following increased moisture supply is expected as moisture stress has been found to limit proper vegetative growth and development. Similar result of decrease in growth attributes following imposition of various stress regimes were obtained by Falaki, (1994), Kumar et al. (1990), Acevedo et al. (1971) and Boyer (1976).

The decrease in number of days to maturity at the lower irrigation levels was probably a hormone-induced response to stress to hasten the development of the plant. A similar hormonal response to temperature and light stress was documented by Campbell et al. (1981) and supports the present finding.

The increase of irrigation regime from $60 \%$ ASM to $90 \%$ only marginally increased grain yield in two seasons (1995/96 and 1996/97). In 1997/98 Season, however grain yield increased significantly with increase in irrigation regime. The lack of significant increase of grain yield in the two seasons at higher irrigation regimes was probably due to the high water table of the experimental site used. Hank et al. (1977) found insignificant influence of irrigation treatments on yield of corn and alfalfa and ascribed the lack of response to upward flow of water through capillary spaces from high water table into the root zone. Eckert et al. (1978) also reported a similar lack of response to irrigation treatments in their experiment that was conducted under higher water table. The results indicate that irrigation at $60 \%$ ASM was sufficient for the cultivation of wheat at Kadawa. This moisture regime is less than $75 \%$ ASM reported by Falaki $(1994$, , ) and about $15 \%$ and $10 \%$ more than $50 \%$ ASM at which Kumar (1979) and Singh et al. (1980) respectively, obtained the best water use efficiency. However, the $60 \%$ ASM falls within the range of $60-70 \%$ ASM recommended by Erie (1962) for wheat cultivation at Arizona.

Yield components such as weight of spike, number of spike $/ \mathrm{m}^{2}$ number of sterile spikelet, 1000 grain weight, harvest index, grain weight and grain number per spike were not influenced by the irrigation treatments in the same manner as the grain yield. The lack of response of these yield attributes to the irrigation treatments may have accounted for the insignificant differences in grain yield.

Thermal energy accumulation increased with increased irrigation regime because of the increase in maturity duration occasioned by the high moisture condition.

The total irrigation water use by maintaining irrigation at $60 \%$ ASM in the three-year study ranged from $595 \mathrm{~mm}$ to $604 \mathrm{~mm}$. This range is less than the range of $650-850 \mathrm{~mm}$ obtained under a fixed irrigation interval by Siewierski (1970), and Maurya and Sachan (1985) at Ngala and Kadawa respectively. The range was also remarkably lower than 720 - $1080 \mathrm{~mm}$ obtained by Kuzniar et al. (1989) at Bakura. 


\section{INTERACTION BETWEEN VARIETY AND IRRIGATION REGIME}

Decreasing moisture stress from $60 \%$ to $90 \%$ ASM increased the number of days to maturity more in Siete cerros than Pavon 76, because of the genetic difference and difference in their length of maturity. Since Pavon 76 matured earlier, it was less exposed to the adverse high temperature regime that set in later in each season hence its was less adversely affected compared with Siete cerros as similarly reported by Kajdi (1993). Also, the effect of increased moisture stress on thermal energy accumulated (degree-days) at maturity was more profound in Siete cerros because it matured later and was therefore exposed more to late occurring higher temperature regimes than Pavon 76. Water use efficiency of Pavon 76 was consistently higher than that of Siete cerros at each of the irrigation levels evaluated because it used less water and gave higher yields. The fact that both variety gave the highest WUE at $60 \%$ ASM suggests that their optimum irrigation regime is about the same.

\section{CORRELATON}

A positive and highly significant relationship was observed between grain yield and most of the growth and yield characters, indicating a high degree of interdependency between the characters. The high level of significance between grain yield and characters such as LAI, number of spike/m², grain weight/spike, grainfilling duration and harvest index total indicate that the characters are vital yield determinants. This is in line with findings of Kinyera and Ayiecho (1992), and Abubakar (1999). The negative correlation between 1000 grain weight and attributes such as number of grain /spike and grain weight/spike indicate some compensatory tendencies among these yield attributes. Also the inconsistency in the level of significance in terms of the correlation between grain yield and number of grain/spike or 1000grain weight suggests that the level of compensation among the attributes could vary between seasons. Negedu (1994) obtained similar result that supports this explanation.

The lack of significant correlation between grain yield and water use probably imply that moisture was not very limiting in the experiment. Viets (1962) reached similar conclusion.

\section{CONCLUSION}

The results of the study indicate that irrigation at $60 \%$ ASM is adequate for both varieties of wheat at the Sudan savanna location where the experiment was conducted. It seems from the study that grain number per spike rather than high tillering and large seed size characteristics are more relevant to grain yield.

\section{REFERENCES}

ABUBAKAR (I. U.). 1999. Effect of basin and interrow spacing on growth, yield and yield components of four wheat (Triticum aestivum L.) varieties. PhD Thesis Ahmadu Bello University, Zaria, 210 p.

ACEVEDO (E.), (J. C.) HSIO AND (D. W.) HENDERSON. 1971. Immediate and subsequent growth response of maize leaves to changes in water stress. Plant physiol. 48 : 631-636.

BAPNA (J. S.) AND (V. S.) KHUSPE. 1980. Effect of different soil moisture regimes and nitrogen levels on moisture used by dwarf wheat. The mysore J. Agric Sci. 14 : 211-214.

BELL (M. A.) and (R. A.) FISCHER. 1994. Guide to plant sampling: Measurements and observations for Agronomic and physiological research in small grain cereals. Wheat special report. $32 ; 66-76$.

BENBI (D. K.). 1994. Prediction of leaf area indices and yields of wheat. J. Agric Sci Camb. $122: 13-20$.

BOYER (J. S.). 1976. Leaf enlargement and metabolic rates in corn, soybean and sunflower at various leaf water potentials. Plant Physiol, $46:$ 233-235.

CAMPBELL (C. A.), (H. R.) DAVISON and (G. E.) WINKLEMAN. 1981. Effect of Nitrogen, temperature, growth stage and duration of moisture stress on yield components and protein content of Manitou Spring wheat. Can. J. Plant Sci., 61 : 549 -563.

DUNCAN (D. B.). 1955. Multiple range and multiple F. test. Biometrics, $11: 1-41$.

ECKERT (J. B.), (N. M.) CHANDHRY and (S. A.) WURESHI. 1978. Water and nutrient response of semi-dwarf wheat under improved management in Pakistan : Agronomic and Economic Implications. Agron. J., $70: 77$ - 80.

ERIE (L. J.). 1962. Closing irrigation gap. Cotton Trade J. Inst Ed., 29 : 234-236. 
FALAKI ( A. M.). 1994. Response of dwarf wheat varieties (Triticum aestivum L.) to different water Stress levels dates of sowing and nitrogen fertilization. PhD thesis, Ahmadu Bello University, Zaria $p$.

HANKS (R. J.), (T. E.) SULLIVAN and HUNSAKER. 1977. Corn and Alfalfa production as influenced by irrigation and salinity. Soil Sci. Soc. of A.M. J. 41 : 606-612.

HANSON (H.), (N. E.) BORLANG and (R. G.) ANDERSON. 1982. Wheat in the third World. Westview Press, Colorado $174 \mathrm{p}$.

HE (E. G.) and (S.) RAJARAM. 1993. Differential response of bread wheat characters to high temperatures. Euphytica, 72 : 197-203.

KAJDI (F.). 1993. Effect of irrigation on the yield of winter wheat varieties. Alta agronomica Ovariensis ; $35: 221-231$.

$\operatorname{KHEHR}($ E.), (A. F.) MATTA, (S. E. G.) WAHBA and (M. M.) EL-KOLIEY. 1996. Effect of wate regime on yield of some maize cultivars and water relations. Fac. Agric,. University of Cairo Crop Res. Inst. Egypt. Res. Bull., 47. 87-98 p.

KINYERA (M. G.) and (P. O.) AYIECHO. 1992. Correlation studies to facilitate the selection of bread wheat varieties for marginal areas of Kenya. In (P. G.) Tanner and (W. J.) Nwangi (Ed.). $7^{\text {th }}$ Regional wheat workshop for eastern, central an southern Africa. Mexico DF : 142 - 157.

KUMAR (V.). 1992. Appropriate cropping pattern for irrigated Agriculture in Nigerian Savanna National Workshop on impact of Irrigation projects on Nigeria socio-economic and ecological environ-ment at Obafemi Awolowo University, Ile-Ife Nigeria July 26028 1992, 14 p.

KUMAR (V.) and (J. Y.) YAYOCK. 1980. Growth stages and productivity of wheat at two dates of planting at Samaru. $7^{\text {th }}$ National irrigation seminar held at Baguada Lake Hotel Kano, 8 - 12 September 1980, 17 p.

KUZNIAR (A.), (J. A.) AREMU, (A.) GALKA and (L.) SING. 1989. Irrigation frequency and nitrogen requirements of wheat crop under sprinkler irrigation. Progress in Irrigation Research. A report of terminal experiments submitted to the $P$ \& A Board, 21 and 22
February 1989, IAR, Ahmadu Bello University, Zaria : 31-36

LARGE (E. C.). 1954. Growth stages in cereals. Illustrations of Feekes scales. Plant Pathol. 31: $128-129$

MAURYA (PO. R.) and (R. S.) SACHAN. (1985). Irrigation Scheduling in relation to salt buildup under varying ground water table conditions. $5^{\text {th }}$ Agro-Asian Regional Conf. of ICED) Townville, Australia).

MICHAEL (A. M.). 1978. Irrigation. Theory and Practice. Vikas Pub. PVT Ltd. New Delhi, $584 \mathrm{p}$.

NEGEDU (S.). 1994. Growth yield and nitrogen uptake of awned and awnless wheat as affected by Nitrogen and row spacing. A. PhD thesis. Ahmadu Bello University, Zaria, $196 \mathrm{p}$.

NWA (E. U.). 1982. Ground water problems of the Kano River project of Nigeria. $4^{\text {th }}$ Afro-Asian Regional Conf. Of ICDI, Lagos Nigeria. Paper $N^{\circ} .10: 123-127$.

ORAKWE (F.) and (L.) OLUGBEMI. 1990. Status of irrigated wheat in Nigeria : Research priorities. In Rayar et al (Ed.). Wheat in Nigeria: Production processing and utilization. I. A. R., L. C. R.I, and UNIMAID : 77-85.

RAJARAM (S.) and (M.) VAN GIMKEL. 1996. Yield potential debate : Germplasm VS. Methodology or both. In Reynolds et al. (Ed.). Increasing yield potential of wheat: Breaking the barriers. CIMMYT Mexico DF : 342-347.

SLAYTER (R. O.). 1967. Plant Water Relationship. Academy Press. London. $342 \mathrm{p}$.

SINGH (G. P. N.) SINGLE and (L. S.) BHUSHAN. 1980. Water used and wheat yields in Northern India under different irrigation regimes. Agric Water Mgmt. $3: 107-114$.

SIEWIERSKI (E.). 1979. Wheat irrigation research at Ngala. Progress on Irrigation Research Programme 1978 - 79. IAR Ahmadu Bello University Zaria. $42 \mathrm{p}$.

SNEDECOR (G. W.) and (W. G.) COCKRAN. 1967. Statistical methods. $6^{\text {th }}$ Ed. lowa State Univ. Press. Ames, lowa USA. 342 p.

VIETS (F. G. Jr.). 1962. Fertilizer and the efficient use of water. Adv. in Agron. 14 : 123-164. 